\title{
GC-MS Analysis and Antibacterial Activity of Aerial Parts of Quisqualis indica Plant Extracts
}

\author{
Akriti Agarwal, Rajmani Prajapati, Sayed Kalve Raza, Lalitesh Kumar Thakur* \\ Institute of Pesticide Formulation Technology Sector-20, Udyog Vihar, Gurgaon-122 016, Haryana, INDIA.
}

\begin{abstract}
Background: Bacteria is an important group of human pathogens that causes various types of diseases. Plants are the traditional sources for many chemicals used as pharmaceutical biochemicals, fragrances, food colors and flavors in different countries especially in India. Quisqualis indica Linn. belongs to a family Combretaceae which is commonly known as Rangoon creeper has great medicinal values. Objective: To analyze the chemical constituents present in different solvent extracts of $Q$. indica using gas chromatography-mass spectroscopy (GC-MS) and evaluation of their antibacterial activities against human pathogens. Method: The dried aerial part of plant was extracted using three solvents like methanol, ethyl acetate and hexane at room temperature for 6 hours separately and antibacterial activity was carried out by broth dilution method. Results: 15, 12 and 18 compounds were confirmed by GC-MS qualitatively in methanol, ethylacetate and hexane extracts respectively. All extracts showed significant activity against four bacteria: Escherichia coli, Klebsiella pnemoniae, Staphylococcus aureus and Staphylococcus pneumonia which were comparable with ampicillin drug taken as positive control. Conclusion: The antibacterial result indicates that the aerial parts of plant have antibacterial activities due to presence of various phytochemical constituents. All the major components confirmed by GC-MS from different extract are biologically active molecule which indicates that the plant might have some medicinal properties.
\end{abstract}

Key words: Antibacterial activity, GC-MS analysis, Phytochemicals constituents, Quisqualis indica.

\section{INTRODUCTION}

Nature has been as source of medicinal agent for thousands of years and an impressive number of modern drugs have been isolated from natural sources. Various medicinal plants have been used as a source of medicine for years in daily life to treat diseases all over the world. ${ }^{1} Q$. indica Linn. commonly known as Rangoon Creeper is an excellent vine for outdoor gardens belonging to family Combretaceae. Some medicinal properties of Q. indica Linn. has been documented in Ayurveda, Siddha, Unnani and other medicinal system. ${ }^{2}$ Almost all of its parts are used individually or mixed with other ingredients as remedy to different ailments like antiflatulence, coughs, diarrhea, ${ }^{3}$ body pains, antlelmintic, toothache, ${ }^{4}$ and cardiovascular system, ${ }^{5}$ Herbs that are rich in flavonoids, vitamin $\mathrm{C}$ or the carotenoids may enhance immune function. ${ }^{6}$ A number of pharmacological studies have been reported on Q. indica Linn., immunomodulatory, ${ }^{7-9}$ antibacterial, antioxidant, ${ }^{10}$ antipyretic, anthelmintic, ${ }^{11}$ antirrhumatic properties, ${ }^{12}$ antiviral, antifungal, ${ }^{13}$ anti-inflammatory, anti-staphylococcal and antiseptic properties ${ }^{14}$ due to the presence of various phytochemical constituents all over the parts of plants. Its seeds and leaves are used for therapeutic purposes, like antigelmintoznoe tool, especially against tapeworm as well as a sedative. It has also been reported to be used successfully against stomach pain, cold, skin parasites, and rickettsia. ${ }^{15}$ The leaf extract of Q. indica Linn. contain phytochemical such as quinone, flavonoids, Tannin, Phenolic,
Submission Date: 30-08-2016; Revision Date: 17-11-2016; Accepted Date: 23-11-2016

DOI: 10.5530/ijper.51.2.39 Correspondence: Lalitesh Kumar Thakur, Institute of Pesticide Formulation Technology Sector-20, Udyog Vihar,

Gurgaon-122 016 Haryana, INDIA.

Tel: +91-124-2341361, Fax-+91-124-2348489 E-mail: thakurlk1964@ rediffmail.com

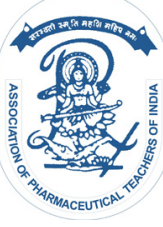

www.ijper.org 
Saponin compound and cumarin, quinone and flvonoid. ${ }^{16}$ The Flavonoids are a group of phenolics that are found in varying amounts in foods and medicinal plants which have been shown to exert anti-allergic, anti-inflammatory, ${ }^{17}$ anti-microbial and antihepatotoxic activities. ${ }^{18}$ One of the reason of using this plant in making many herbal products is its availability almost in every season and also it grows faster. ${ }^{14}$

The aim of present work was to analyze phytochemical constituents present in aerial parts of the plant extracts using methanol, ethylacetate and hexane by GC-MS and evaluate the antibacterial activity of these extracts.

\section{MATERIALS AND METHODS}

\section{Materials}

The plant Q. indica Linn. was collected from Gurgaon, Haryana (India) in November 2014. Methanol, ethylacetate and hexane (HPLC grade) were procured from Merck, India. The plant was identified by the scientist of the Institute.

\section{Methods}

The aerial parts of the plant was collected, washed, air dried in shadow and grinded by mixer grinder. After grinding, $5 \mathrm{gm}$ of plant material was extracted in $50 \mathrm{ml}$ of different solvents (methanol, ethylacetate, and hexane) separately at room temperature for 6 hours. The organic solvent was filtered by whatman filter paper till clear solution was obtained. Solvent was evaporated in a rotatory evaporator (Buchi, Switzerland) under reduced pressure (vacuum) at $40-50^{\circ} \mathrm{C}$ till complete dryness. For phytochemical analysis, $1000 \mathrm{ppm}$ solution of each extract was prepared separately by dissolving $1 \mathrm{mg}$ dried plant material in $1 \mathrm{ml}$ of the same fresh HPLC grade solvent.

\section{GC-MS analysis}

The chromatographic procedure was performed using GC-MS model MSQP2010 (Shimadzu, Kyoto, Japan) with auto sampler. $1000 \mathrm{ppm}$ solution in methanol, ethylacetate and hexane were prepared from three extracts (methanol, ethylacetate and hexane) and $1 \mu \mathrm{L}$ of each extract was injected for analysis using DB -5MS column (30 meter $\times 0.25 \mathrm{~mm}$, film thickness $0.25 \mu \mathrm{m})$. Helium gas was used at flow rate $1 \mathrm{ml} / \mathrm{min}$. as a carrier gas. The analysis was carried out using oven programming of initial temperature $50^{\circ} \mathrm{C}$ for 2 minutes followed by ramp rate of $20^{\circ} \mathrm{C} /$ minute up to $130^{\circ} \mathrm{C}$ followed by ramp of $12^{\circ} \mathrm{C} / \mathrm{min}$. to a temperature of $180^{\circ} \mathrm{C}$, finally raised temperature to $280^{\circ} \mathrm{C}$ at $3^{\circ} \mathrm{C}$ per minute and hold for 15 minutes. The ion source temperature was set at $250^{\circ} \mathrm{C}$. The injection port temperature was set as a $250^{\circ} \mathrm{C}$ and the total run time was 58.5 minute. The instrument was operated in electron impact (EI) mode with electron energy $70 \mathrm{ev}$. Confirmation of analytes was done by SIM (selective ion mode) mode. ${ }^{19,20}$

\section{Evaluations of antibacterial studies}

Antibacterial studies of different plant extracts (methanol, ethylacetate, and hexane) of $Q$. indica Linn. were done against four bacteria species E. coli, K. pneumonia, $S$. aureus and $S$. pnemoniae. The study was carried out using the broth dilution technique by 2 -fold serial dilution method to determine minimum inhibitory concentration (MIC). The procedure involves preparing two-fold dilutions of the antimicrobial agent (e.g. 6.25, 12.5, 25, $50,100,200$ and $400 \mu \mathrm{g} / \mathrm{mL}$ ) in a liquid growth medium. The MIC is the lowest concentration of antimicrobial agent that inhibits growth of the organism as detected by the unaided eye. After getting the MIC value, the experiment has been done in triplicate nearest the MIC value. The antibacterial study was done from Micropharm Diagnostic Center, Gandhinagar, Gujarat, India.

\section{Statistical Analysis}

All the experiments were conducted in triplicate and statistical analyses were conducted using one way analysis of variance (ANOVA). The results were expressed as means of triplicate determinations \pm standard deviation (SD). P values $<0.05$ were considered as significant.

\section{RESULTS}

The plant extracts of $Q$. indica (methanol, ethylacetate and hexane extracts) were analyzed by GC-MS. The presence of components was confirmed by comparing mass spectra of analyzed components with standard mass spectra of NIST and Willey library. In the GC-MS analysis of Q. indica, 12 compounds were confirmed in ethyl acetate extract, 18 in hexane extract while 15 compounds in methanol extract. The active principles with their retention time (RT), molecular formula, molecular weight (MW), concentration (\%), base ion and other fragment ion in methanol, ethylacetate and hexane extracts of $Q$. indica are presented in Table 1, 2, and 3 respectively. Chromatogram of methanol, ethylacetate and hexane extracts are shown in Fig. 1, 2 and 3 respectively and the structures of all the confirmed components are given in Scheme 1.

The major 15 compounds which were found in methanol extract are diethylphthalate $(0.16 \%)$, isobutyl-o-phthalate $(0.04 \%)$, methyl isohexadecanoate $(0.18 \%)$, phytol isomer $(8.69 \%)$, methyl tetradecanoate- $12-\mathrm{Me}(0.07 \%)$, methyl linolelaidate $(0.039 \%), 7,10,13$-hexadecatrienal 


\begin{tabular}{|c|c|c|c|c|c|c|}
\hline \multicolumn{7}{|c|}{ Table 1: Phytochemicals detected in methanol extract. } \\
\hline $\mathbf{R T}$ & Compound name & $\begin{array}{c}\text { Molecular } \\
\text { weight }\end{array}$ & $\begin{array}{c}\text { Molecular } \\
\text { formula }\end{array}$ & $\%$ area & Base ion & Other fragments ion (m/z) \\
\hline 11.002 & Diethylphthalate & 222 & $\mathrm{C}_{12} \mathrm{H}_{14} \mathrm{O}_{4}$ & 0.16 & 149 & $75,105,177,222$ \\
\hline 14.444 & Isobutyl-o-phthalate & 278 & $\mathrm{C}_{16} \mathrm{H}_{22} \mathrm{O}_{4}$ & 0.04 & 149 & $57,104,223$ \\
\hline 15.343 & Methyl isohexadecanoate & 270 & $\mathrm{C}_{17} \mathrm{H}_{34} \mathrm{O}_{2}$ & 0.18 & 74 & $55,97,143,171,185,227,270$ \\
\hline 18.533 & Methyl linolelaidate & 266 & $\mathrm{C}_{17} \mathrm{H}_{30} \mathrm{O}_{2}$ & 0.39 & 67 & $81,96,123,150,235$ \\
\hline 18.953 & Phytol & 296 & $\mathrm{C}_{20} \mathrm{H}_{40} \mathrm{O}$ & 8.69 & 71 & $57,81,95,111,123,137$ \\
\hline 19.206 & Methyl tetradecanoate,12-Me & 256 & $\mathrm{C}_{16} \mathrm{H}_{32} \mathrm{O}_{2}$ & 0.07 & 74 & $55,97,143,157,199,213$ \\
\hline 32.055 & $7,10,13-h e x a d e c a t r i e n a l$ & 234 & $\mathrm{C}_{16} \mathrm{H}_{26} \mathrm{O}$ & 1.17 & 79 & 67,108 \\
\hline 35.084 & trans Squalene & 410 & $\mathrm{C}_{30} \mathrm{H}_{50}$ & 7.70 & 69 & $55,95,149,191,203$ \\
\hline 36.645 & $1-$ Dotriacontanol & 466 & $\mathrm{C}_{32} \mathrm{H}_{66} \mathrm{O}$ & 0.59 & 57 & $83,97,125,153$ \\
\hline 37.353 & Nerolidol isomer & 222 & $\mathrm{C}_{15} \mathrm{H}_{26} \mathrm{O}$ & 0.15 & 69 & $109,81,135$ \\
\hline 39.794 & Tocoferol & 416 & $\mathrm{C}_{28} \mathrm{H}_{48} \mathrm{O}_{2}$ & 1.22 & 151 & $71,107,122,151,191,416$ \\
\hline 41.474 & Vitamin E acetate & 472 & $\mathrm{C}_{31} \mathrm{H}_{52} \mathrm{O}_{3}$ & 3.19 & 165 & $57,91,121,136,177,430$ \\
\hline 44.746 & Stigmasterol & 412 & $\mathrm{C}_{29} \mathrm{H}_{48} \mathrm{O}$ & 7.73 & 55 & $69,83,105,145,173,213,271,314$ \\
\hline 45.404 & Viridiforol & 222 & $\mathrm{C}_{15} \mathrm{H}_{26} \mathrm{O}$ & 3.44 & 69 & $81,93,109,161,189$ \\
\hline 47.005 & Cycloartenyl acetate & 468 & $\mathrm{C}_{32} \mathrm{H}_{52} \mathrm{O}_{2}$ & 6.78 & 69 & $81,109,135,149,175,393$ \\
\hline & Unknown & & & 58.5 & & \\
\hline
\end{tabular}

\begin{tabular}{|c|c|c|c|c|c|c|}
\hline \multicolumn{7}{|c|}{ Table 2: Phytochemicals detected in ethylacetate extract. } \\
\hline RT & Compound name & $\begin{array}{c}\text { Molecular } \\
\text { weight }\end{array}$ & $\begin{array}{c}\text { Molecular } \\
\text { formula }\end{array}$ & $\%$ area & $\begin{array}{c}\text { Base } \\
\text { ion }\end{array}$ & Other fragments ion (m/z) \\
\hline 7.319 & Dodecane & 170 & $\mathrm{C}_{12} \mathrm{H}_{26}$ & 0.08 & 57 & 71,98 \\
\hline 9.116 & Heptadecane & 240 & $\mathrm{C}_{17} \mathrm{H}_{36}$ & 0.09 & 57 & $71,99,127,155$ \\
\hline 10.138 & Farnesene & 204 & $\mathrm{C}_{15} \mathrm{H}_{24}$ & 0.07 & 93 & $69,107,119$ \\
\hline 18.965 & Phytol & 296 & $\mathrm{C}_{20} \mathrm{H}_{40} \mathrm{O}$ & 8.00 & 71 & $57,81,95,111,123,137$ \\
\hline 32.26 & Octacosane & 394 & $\mathrm{C}_{28} \mathrm{H}_{58}$ & 1.05 & 57 & $71,99,127,155,183$ \\
\hline 35.087 & trans squalene & 410 & $\mathrm{C}_{30} \mathrm{H}_{50}$ & 8.60 & 69 & $55,95,149,191,203$ \\
\hline 36.709 & Pentatriacotane & 492 & $\mathrm{C}_{35} \mathrm{H}_{72}$ & 4.10 & 57 & $71,85,113,127,155,169$ \\
\hline 39.739 & Gama- tocopherol & 416 & $\mathrm{C}_{28} \mathrm{H}_{48} \mathrm{O}_{2}$ & 1.22 & 151 & $71,107,191$ \\
\hline 40.968 & Tetratetraacotane & 618 & $\mathrm{C}_{44} \mathrm{H}_{90}$ & 12.3 & 57 & $71,85,113,127,155,169,197,211,225$ \\
\hline 41.474 & Vitamin E acetate & 472 & $\mathrm{C}_{31} \mathrm{H}_{52} \mathrm{O}_{3}$ & 3.93 & 165 & $57,91,121,136,177,430$ \\
\hline 44.743 & Stigmasterol & 412 & $\mathrm{C}_{29} \mathrm{H}_{48} \mathrm{O}$ & 6.94 & 55 & $69,81,95,105,119,173,215,412$ \\
\hline 45.013 & Heptacosane-1-chloro & 414 & $\mathrm{C}_{27} \mathrm{H}_{55} \mathrm{Cl}$ & 7.04 & 57 & $71,113,141,183$ \\
\hline- & Unknown compound & & & 46.58 & & \\
\hline
\end{tabular}

$(1.17 \%)$, trans Squalene $(7.70 \%), 1$ - dotriacontanol ( $0.59 \%)$, nerolidol isomer $(0.15 \%)$ tocoferol $(1.22 \%)$, vitamin E acetate (3.19\%), sigmasterol (7.73\%), viridiforol $(3.44 \%)$ and cycloartenyl acetate $(6.78 \%)$.

12 Compounds which were detected in ethylacetate extract by GC-MS are dodecane ( $0.08 \%$ ), heptadecane $(0.09 \%)$, farnesene $(0.07 \%)$, phytol $(8.00 \%)$, octacosane $(1.05 \%)$, trans squalene $(8.60 \%)$, pentatriacotane $(4.10 \%)$, gama-tocopherol $(1.22 \%)$, tetratetraacotane $(12.3 \%)$, vitamin $\mathrm{E}$ acetate (3.92\%), heptacosane-1- chloro (7.95\%) and heptacosane-1-chloro (7.04\%).

In hexane extract, 18 compounds were identified by GC-MS which are pentadecane $(0.18 \%)$, farnesene $(0.07 \%)$, farnesane $(0.06 \%)$ 6-methyl octdecane $(0.02 \%)$, heptadecane $(0.16 \%)$, methyl palmitate $(10.43 \%)$, methyl hexadeconate $(1.93 \%)$, methyl linolate $(8.69 \%)$, phytol $(1.24 \%)$, methyl stereate $(1.03 \%)$ octacosane $(0.62 \%)$, trans-squalene $(5.12 \%)$, pentatriacotane $(3.17 \%)$, gamatocopherol $(0.77 \%)$, tetratetracontane $(7.18 \%)$, vitamin 


\begin{tabular}{|c|c|c|c|c|c|c|}
\hline RT & Compound name & $\begin{array}{c}\text { Molecular } \\
\text { wt }\end{array}$ & $\begin{array}{l}\text { Molecular } \\
\text { formula }\end{array}$ & $\%$ area & Base ion & Other fragments ion $(\mathrm{m} / \mathrm{z})$ \\
\hline 9.120 & Pentadecane & 212 & $\mathrm{C}_{15} \mathrm{H}_{32}$ & 0.18 & 57 & $71,99,127,155$ \\
\hline 10.140 & Farnesene & 204 & $\mathrm{C}_{15} \mathrm{H}_{24}$ & 0.07 & 93 & $69,107,123$ \\
\hline 10.425 & Farnesane & 212 & $\mathrm{C}_{15} \mathrm{H}_{32}$ & 0.06 & 57 & $71,99,127$ \\
\hline 10.69 & 6-methyl octdecane & 268 & $\mathrm{C}_{19} \mathrm{H}_{40}$ & 0.02 & 57 & $71,99,127$ \\
\hline 13.386 & Heptadecane & 240 & $\mathrm{C}_{17} \mathrm{H}_{36}$ & 0.16 & 57 & $71,99,127$ \\
\hline 15.346 & Methyl hexadeconate & 270 & $\mathrm{C}_{17} \mathrm{H}_{34} \mathrm{O}_{2}$ & 1.93 & 74 & $55,57,87,97,115,129,143$ \\
\hline 18.575 & Methyl palmitate & 294 & $\mathrm{C}_{19} \mathrm{H}_{34} \mathrm{O}_{2}$ & 10.43 & 67 & $55,81,95,96,109,123,135,294$ \\
\hline 18.711 & Methyl linolate & 292 & $\mathrm{C}_{19} \mathrm{H}_{32} \mathrm{O}_{2}$ & 8.69 & 79 & $55,67,93,108,121,122,135,149,292$ \\
\hline 18.952 & phytol & 296 & $\mathrm{C}_{20} \mathrm{H}_{40} \mathrm{O}_{2}$ & 1.24 & 71 & $57,95,123,196$ \\
\hline 19.213 & Methyl stereate & 298 & $\mathrm{C}_{19} \mathrm{H}_{38} \mathrm{O}_{2}$ & 1.03 & 74 & $55,97,143,199,255,298$ \\
\hline 32.26 & Octacosane & 394 & $\mathrm{C}_{28} \mathrm{H}_{58}$ & 0.62 & 57 & $71,99,127,155,183,211$ \\
\hline 35.088 & Trans - squalene & 410 & $\mathrm{C}_{30} \mathrm{H}_{50}$ & 5.12 & 69 & $55,95,161,191,203,410$ \\
\hline 36.79 & Pentatriacotane & 492 & $\mathrm{C}_{35} \mathrm{H}_{72}$ & 3.17 & 57 & $71,85,113,127,155,169$ \\
\hline 39.79 & Gama - tocopherol & 416 & $\mathrm{C}_{28} \mathrm{H}_{48} \mathrm{O}_{2}$ & 0.77 & 151 & $57,191,416$ \\
\hline 40.96 & Tetratetracontane & 618 & $\mathrm{C}_{44} \mathrm{H}_{90}$ & 7.18 & 57 & $71,85,113,127,155,169$ \\
\hline 41.488 & Vitamin $E$ acetate & 472 & $\mathrm{C}_{31} \mathrm{H}_{52} \mathrm{O}_{3}$ & 3.92 & 165 & $57,91,121,136,177,430$ \\
\hline 44.752 & Stigmesterol & 426 & $\mathrm{C}_{30} \mathrm{H}_{50} \mathrm{O}$ & 4.67 & 55 & $105,145,173,213$ \\
\hline 45.018 & Heptacosane-1-chloro & 414 & $\mathrm{C}_{27} \mathrm{H}_{55} \mathrm{Cl}$ & 7.95 & 57 & $71,113,141,183$ \\
\hline- & Unknown compound & & & 42.79 & & \\
\hline
\end{tabular}

\section{Table 4: Antibacterial activities of aerial parts of plant extracts using different solvents.}

\begin{tabular}{|c|c|c|c|c|c|}
\hline \multicolumn{5}{|c|}{ Minimal inhibition concentration $(\boldsymbol{\mu g} / \mathrm{ml})$} \\
\hline S.No. & Extract & E. coli. & KI. pnemoniae & S. aureus & S. pnemoniae \\
\hline 1 & Ethyl acetate & $100 \pm 1$ & $50 \pm 0.5$ & $25 \pm 0.2$ & $50 \pm 0.3$ \\
\hline 2 & Hexane & $50 \pm 0.25$ & $12.5 \pm 0.5$ & $25 \pm 0.5$ & $100 \pm 0.5$ \\
\hline 3 & Methanol & $12.5 \pm 0.5$ & $50 \pm 1$ & $25 \pm 1$ & $100 \pm 0.75$ \\
\hline 4 & Ampicillin drug (+ve control) & $100 \pm 0.5$ & $100 \pm 0.45$ & $250 \pm 0.5$ & $100 \pm 0.4$ \\
\hline
\end{tabular}

Values are mean of triplicate readings \pm Standard Deviation (mean \pm S.D).

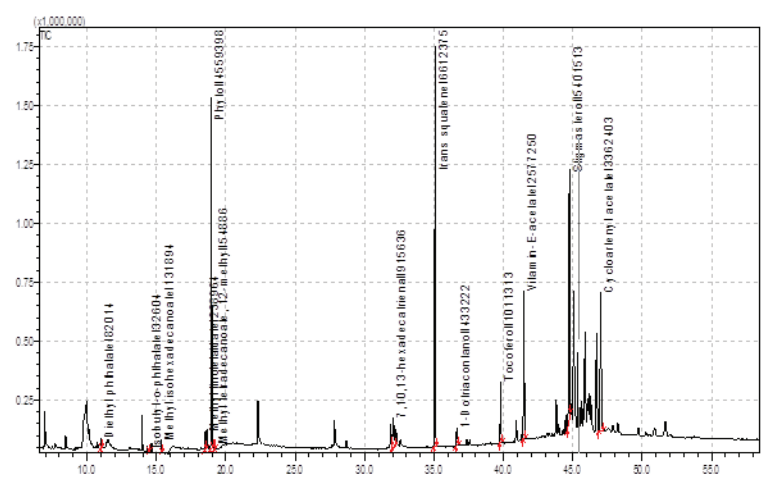

Figure 1: Chromatogram of methanol extract of $Q$. indica.

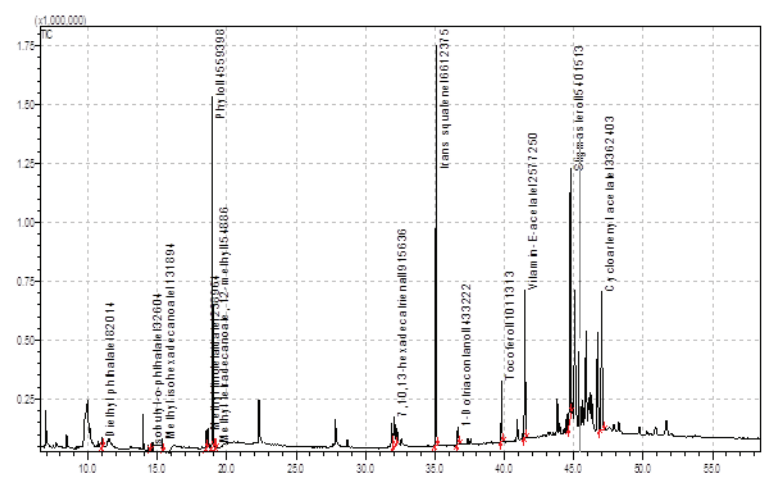

Figure 2: Chromatogram of ethylacetate extract of $Q$. indica. 
E acetate $(3.92 \%)$, heptacosane-1- chloro $(7.95 \%)$ and stigmesterol $(4.67 \%)$.

The maximum unknown chemical components were found in methanol extract i.e. 58.5\% while minimum unknown chemical components were found in hexane extracts i.e. $42.79 \%$. In ethylacetate extract, the unknown chemical constituents were found to be $46.58 \%$.

The antibacterial activity observed among the various solvent extracts of $Q$. indica are summarised in Table 4. MIC values of ethylacetate extract against E. coli, Kl. Pnemoniae, S. Aureus and S. pnemoniae were found effective to control bacteria at $100 \mu \mathrm{g} / \mathrm{ml}, 50 \mu \mathrm{g} / \mathrm{ml}$, $25 \mu \mathrm{g} / \mathrm{ml}$ and $50 \mu \mathrm{g} / \mathrm{ml}$ concentrations which are

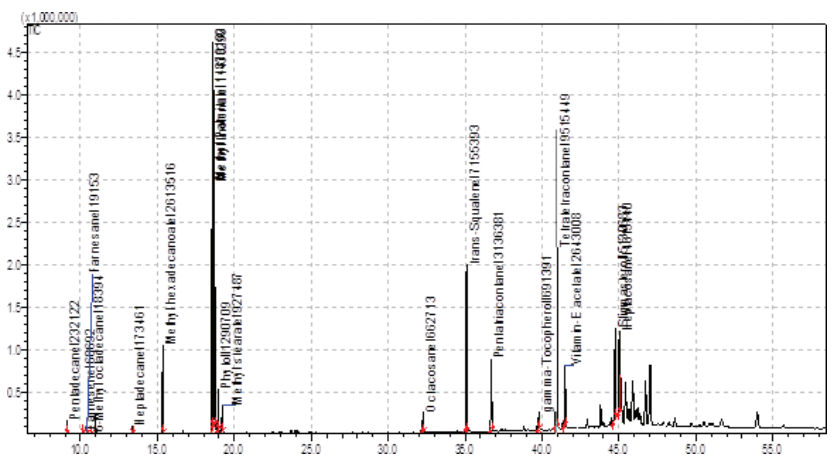

Figure 3: Chromatogram of hexane extract of $Q$. indica.
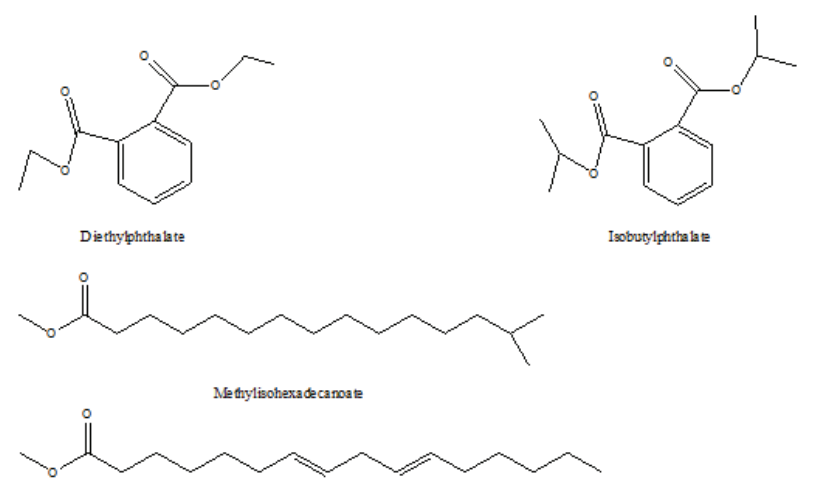

Isobutylphthalas
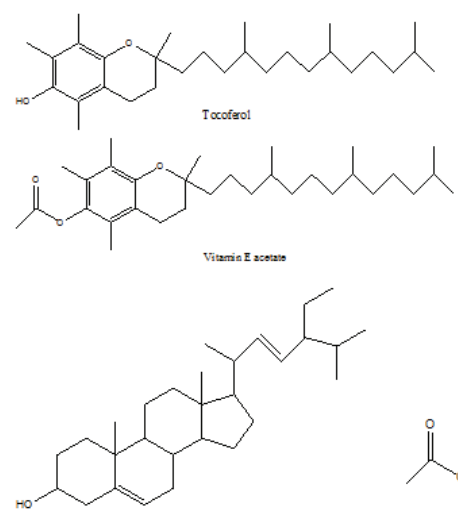

Stigmasterol
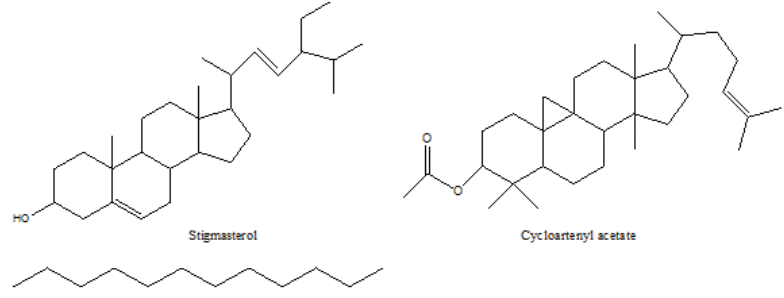

Dodecane

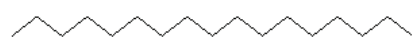

Heptadezane

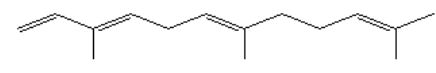

Farnesene

Nm

Octaosane

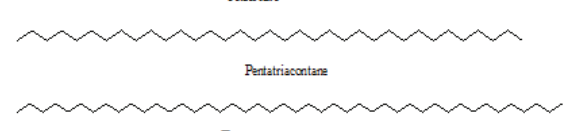

Tetratetracontane

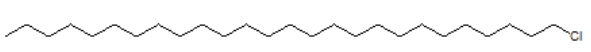

Heptacosane-1-chloro

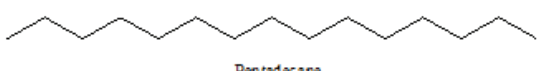

Pentadecane
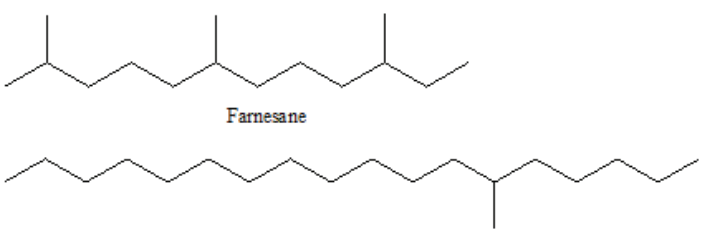

6-Methyl octadecane

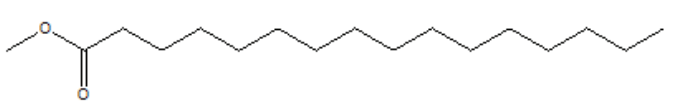

Methyl hexadecanoate

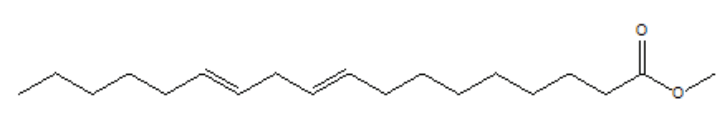

Methy1 palmitate
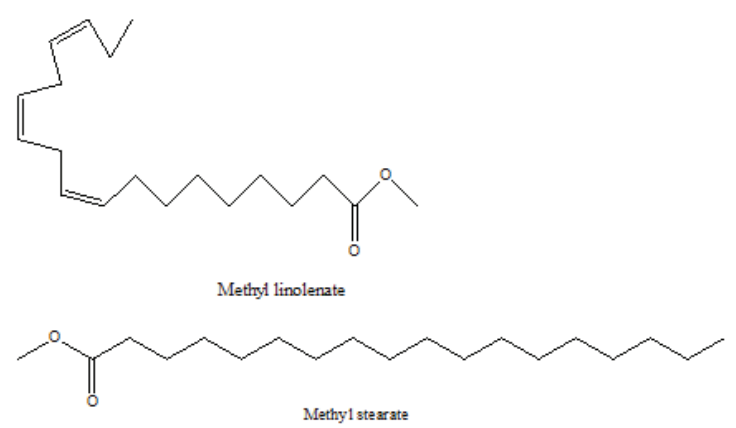

Scheme 4: Structures of confirmed components 
comparable with Ampicillin (+ve control) having values $100 \mu \mathrm{g} / \mathrm{ml}, 100 \mu \mathrm{g} / \mathrm{ml}, 250 \mu \mathrm{g} / \mathrm{ml}$ and $100 \mu \mathrm{g} / \mathrm{ml}$ respectively.

MIC values of hexane against E.coli, Kl. Pnemoniae, S. Aureus and S. pnemoniae were found effective to control bacteria at $50 \mu \mathrm{g} / \mathrm{ml}, 12.5 \mu \mathrm{g} / \mathrm{ml}, 25 \mu \mathrm{g} / \mathrm{ml}$ and $100 \mu \mathrm{g} / \mathrm{ml}$ concentrations which are comparable with Ampicillin (+ve control) having values $100 \mu \mathrm{g} / \mathrm{ml}$, $100 \mu \mathrm{g} / \mathrm{ml}, 250 \mu \mathrm{g} / \mathrm{ml}$ and $100 \mu \mathrm{g} / \mathrm{ml}$ respectively.

MIC values of methanol extract against E.coli, Kl. Pnemoniae, S. Aureus and S. pnemoniae were found effective to control bacteria at $12.5 \mu \mathrm{g} / \mathrm{ml}, 50 \mu \mathrm{g} / \mathrm{ml}, 25 \mu \mathrm{g} / \mathrm{ml}$ and $100 \mu \mathrm{g} / \mathrm{ml}$ concentrations which are comparable with Ampicillin (+ve control) having values $100 \mu \mathrm{g} / \mathrm{ml}$, $100 \mu \mathrm{g} / \mathrm{ml}, 250 \mu \mathrm{g} / \mathrm{ml}$ and $100 \mu \mathrm{g} / \mathrm{ml}$ respectively.

\section{DISCUSSION}

In recent years, the interest for the study of the organic compounds found in plants and their activity has increased. The GC-MS is an ideal technique for qualitative and quantitative analysis of active components in plant. The aim of the present study was to confirm the phytochemicals present in the plant extracts and to evaluate their antibacterial activity. Diversity of medicinal plants and herbs containing various phytochemicals with biological activity can be of valuable therapeutic key. Different phytochemicals have been found to have a broad range of activities, which may help in protection against chronic diseases. ${ }^{21}$

The common constituents found in all the three extracts (methanol, ethylacetate and hexane) are phytol isomer (8.69\% in methanol, $8.0 \%$ in ethylacetate and $1.24 \%$ in hexane), trans squalene $(7.70 \%$ in methanol, $8.60 \%$ in ethylacetate and $5.12 \%$ in hexane), gama tocoferol $(1.22 \%$ in methanol, $1.22 \%$ in ethylacetate and $0.77 \%$ in hexane), vitamin $\mathrm{E}$ acetate (3.19\% in methanol, 3.93\% in ethylacetate and $3.92 \%$ in hexane) and stigmasterol (7.73\% in methanol, 6.94\% in ethylacetate and $4.67 \%$ in hexane).

The GC-MS analysis of the methanol, ethylacetate and hexane extracts resulted many compounds which have many properties. The constituent phytol confirmed in all the solvents having antimicrobial, anticancer, antiinflammatory activity ${ }^{22}$ and is also used in the fragrance industry, cosmetics. ${ }^{23}$ Constituent squalene is also having anti-cancer, anti-oxidant, anti-tumor, chemo-preventive, pesticidal and sun-screen properties. ${ }^{24}$ Compound stigmasterol possesses potent antioxidant, hypoglycemic and thyroid inhibiting properties. ${ }^{25}$

Some constituents who were not present in methanol extract but common in other two solvents i.e. ethylacetate and hexane are farnesene $(0.07 \%$ in ethylacetate and $0.07 \%$ hexane), octacosane $(1.05 \%$ in ethylacetate and $0.62 \%$ in hexane), pentatriacontane $(4.10 \%$ in ethylacetate and $3.17 \%$ in hexane), tetratetracontane $(12.3 \%$ in ethylacetate and $7.18 \%$ in hexane) and heptacosane1-chloro (7.04\% in ethylacetate and $7.95 \%$ in hexane).

Phytol isomer in methanol extract, tetratetracontane in ethylacetate extract and methyl palmitate in hexane extract with their respective areas $8.69 \%, 12.3 \%$ and $10.43 \%$ were found to be major constituents. Tetratetracontane confirmed in ethylacetate extract has antioxidant and cytoprotective activities. ${ }^{26}$ Methyl palmitate in hexane extract has an insect repellent activity. ${ }^{27}$ Some antimicrobial activities of this plant have been previously studied. Hexane, carbon tetrachloride, Chloroform and aqueous fraction of methanolic extract of stem bark and aerial part of this plant were found effective against $S$. aureus and E. coli. ${ }^{28,16}$ Methanol extracts of the flower of this plant was found effective against E. coli. ${ }^{29,30}$

It has been investigated that ethylacetate extract was found most effective against $S$. aureus, least effective against E.coli while Kl. Pnemoniae and S. pnemoniae showed same susceptibility against ethyl acetate extract. Hexane extract was found most effective against Kl. Pnemoniae while least effective against $S$. pnemoniae followed by S. aureus and E.coli. Methanol extract was found most effective against E.coli pathogen while least effective against $S$. pnemoniae follwed by Kl. Pnemoniae and S. aureus. Hexane and methanol extracts showed better efficiency to control selected pathogens followed by ethyl acetate extract. Authors have observed that all extracts of aerial part of Q. indica plant shows better antibacterial activities against selected bacteria as compared to ampicillin drug.

\section{CONCLUSION}

In the present study, total twenty seven chemical constituents have been confirmed from the three different extracts of the aerial parts of plant $Q$. indica by GC-MS analysis. The antibacterial study result indicated that the lowest MIC against E.coli was observed in methanol extract, against Kl. Pnemoniae was found in hexane extract and against $S$. pnemoniae was in ethylacetate whereas against $S$. Aureus the MIC value were same in all the three extracts. The presence of various phytochemical constituents justifies the use of plant for various ailments by traditional practitioners. Thus, this type of GC-MS analysis is the first step towards understanding the nature of active principles in this plant and this type of study will be helpful for further study. The result of this work indicated that the methanol 
and hexane are better solvents than ethylacetate for the extraction of active ingredients of this plant. . Further studies are needed on these extracts in order to isolate, identify, characterize and elucidate the structure of these compounds.

\section{ACKNOWLEDGMENT}

Authors are thankful to Institute of Pesticide Formulation Technology for providing the facility to do such novel work.

\section{CONFLICT OF INTEREST}

Authors declare that there is no conflict of interest.

\section{REFERENCES}

1. Kiruthika KA, Jaisheeba A, Sornaraj R. Evaluation of antibacterial activity of some selected Angiosperm flower extract. International Journal of Chem. Tech. Research. 2011;3(4):1945-51.

2. Bairagi VA, Sadu N, Senthilkumar KL, Ahire Y. Anti-diabetic potential of Quisqualis indica Linn in Rats. Int. J. Pharm. Phytopharmacol. Res. 2012;1(4):166-71.

3. Khare CP. Indian Medicinal Plants. An Illustrated Dictionary. Berlin/ Heidelberg: Springer-Verlag. 2007;649-50.

4. Padua LS, Bunyapraphatsara N. Lemmens RM. Plant Resources of SouthEast Asian Medicinal and Poisonous Plants. Source Backhuys Publications, Leiden, the Netherlands. 1999;12(1):255-9.

5. Nadkarni KM. Nadkarni, Indian material materica, Popular Prakashan private limited, Mumbai. 2007;1:1046.

6. Wetwitayaklung P, Immatvapirat LC, Phaechamud T, Keokitichai S. Kinetics of Acetylcholinesterase Inhibition of Quisqualis indica Linn. Silpakorn U Science \& Tech. J. 2007;2:20-8

7. Ferris H, Zheng L. Plant Sources of Chinese Herbal Remedies: Effects on Pratylenchus vulnus and Meloidogyne javanica. J. of Nemato. 1999;31(3):241-63. PMid:19270895 PMCid:PMC2620379.

8. Bose R, Sushomasri M, Chakraborty P. Free Radical Scavenging Property of Quisqualis indica. Int J Biomed Pharma Sci. 2009;1-4.

9. Wetwitayaklung $P$, Phaechamud T, Keokitichai $S$. The study of antioxidant activities of edible flower. In Proceeding of International Workshop on Medicinal and aromatic Plants, Chiang Mai. Thailand. 2007;75:15-8.

10. Sinozaki $H$, Shibuya L, A new potent excitant, quisqualic acid: effect on crayfish neuromuscular junction. Neuropharmacol. 1974;13(7):665-72. https://doi.org/10.1016/0028-3908(74)90056-2.

11. Effert T, Khal S, Paulus K, Admas M, Rauh R, Hao X. Phytochemistry and pharmacogenomics of natural product derived from traditional Chinese medicine \& Chinese material medica with activity against tumor cells. Mo cancer ther. 2008;7(1):152-71. https://doi.org/10.1158/1535-7163.MCT-070073 PMid:18202018.

12. Ariful HM, Azmal IH, Tridib KP, Mariz S, Himel NK. A survey of medicinal plant usage by folk medicinal practitioners in two villages by the Rupsha River in Bagerhat district, Bangladesh. Am-Eurasian J. Sustainable Agri. 2010;4(3):349-56
13. Kumar M, Sharma G A, In vitro antibacterial activity of flower extracts of Quisqualis indica Linn. against gram-positive and gram-negative bacteria. International Journal of Advances in Pharmacy, Biology and Chemistry. 2014;3(3):781-5.

14. Jyoti S, Patel P K, Dubey B. Quisqualis indica Linn. A Review of its Medicinal Properties. Int. J. Pharm. Phytopharmacol. Res. 2012;1(5):313-21.

15. Sanguri S, Shubhada K, Gopinathan P, Pandey F K, Bhatnagar T. Comparative screening of antibacterial and antifungal activities of some Weeds and medicinal plants leaf extracts: An in-vitro study. Elixir. Appl. Botany. 2012;47:8903-5.

16. Sangeetha P, Balaji R, Bharathi V. Phytochemical and antibacterial effect of Quisqualis indica linn, International Journal of Institutional Pharmacy and Life Sciences. 2015;5(2):32-4.

17. Yamamoto $\mathrm{Y}$, Gaynor RB. Therapeutic potential of inhibition of the NF-kappa B pathway in the treatment of inflammation and cancer. J Clin. Invest. 2001;107(2):135-42. https://doi.org/10.1172/JCl11914 PMid:11160126 PMCid:PMC199180.

18. Nijveldt RJ, Van NE, Van-Hoorn DE, Boelens PG, Van NK, Van-Leeuwen PA. Flavonoids. A Review of Probable Mechanism of Action and Potential Applications. Am J Clin Nutr. 2001;74(4):418-25. PMid:11566638.

19. Abirami P, Rajendran A. GC-MS analysis of methanol extracts of Vernonia cinerea. Euro. J. Exp. Bio. 2012;2(1):9-12.

20. Prajapati R, Roy S, Mishra S, Raza SK, Thakur LK. Formulation development, standardization and antimicrobial activity of ageratum conyzoides extracts and their formulation Int J Pharm Pharm Sci. 2014; 6(2):369-74.

21. Liu RH. Health benefits of fruits and vegetables are from additive and synergic combinations of phytochemicals. Am. J. Clin. Nutr. 2003;78(3):517-20.

22. Grover N. Patni V. Phytochemical characterization using various solvent extracts and GC-MS analysis of methanolic extract of woodfordia fruticosa kurz. Int. J. Pharm. Pharm. Sci. 2013;5(4):291-5

23. Ginty MD, Letizia CS, Api AM. Fragrance material review on phytol. Food and Chem Toxicol. 2010;48:59-63. https://doi.org/10.1016/j.fct.2009.11.012 PMid:20141879.

24. Ezhilan BP, Neelamegam R. GC-MS analysis of phytocomponents in the ethanol extracts of Polygonum chinense L. Pharmacognosy Res. 2012;4(1):11-4. https://doi.org/10.4103/0974-8490.91028 PMid:22224055 PMCid:PMC3250032

25. Panda S, Jafri M, Kar A, Meheta, BK. Thyroid inhibitory, antiperoxidative and hypoglycemic effects of stigmasterol isolated from Butea monosperma Fitoterapia. 2009;80(2):123-6. https://doi.org/10.1016/j.fitote.2008.12.002 PMid:19105977.

26. Ertas A, Yilmaz MA, Firat M. Chemical profile by LC-MS/MS, GC/MS and antioxidant activities of the essential oils and crude extracts of two Euphorbia species. Nat. Prod. Res. 2014;3:1-6.

27. Henderson G, Wells JD, Jeanne RL. Methyl palmitate and methyl myristate repel flies. Fla. Entomol. 1991;74:365-8. https://doi.org/10.2307/3495321.

28. Hussain M, Hussain S, Moin-UI-Islam, Rahman M, Millat S, Sweety MN Exploration of In-vitro antimicrobial and cytotoxic potentials of crude methanolic extracts of Quisqualis indica (stem bark): An ethno medicinal plant International Journal of Biological Research. 2016;4(2):280-7.

29. Kiruthika KA, Jaisheeba AA, Sornaraj R. Evaluation of antibacterial activity of some selected Angiosperm flower extract. International Journal of Chem Tech Research. 2011;3(4):1945-51.

30. Kumar M, Gitika, Sharma A. In vitro antibacterial activity of flower extracts of Quisqualis indica Linn. against gram-positive and gram-negative bacteria IJAPBC. 2014;3(3):781-5. 


\section{PICTORIAL ABSTRACT}

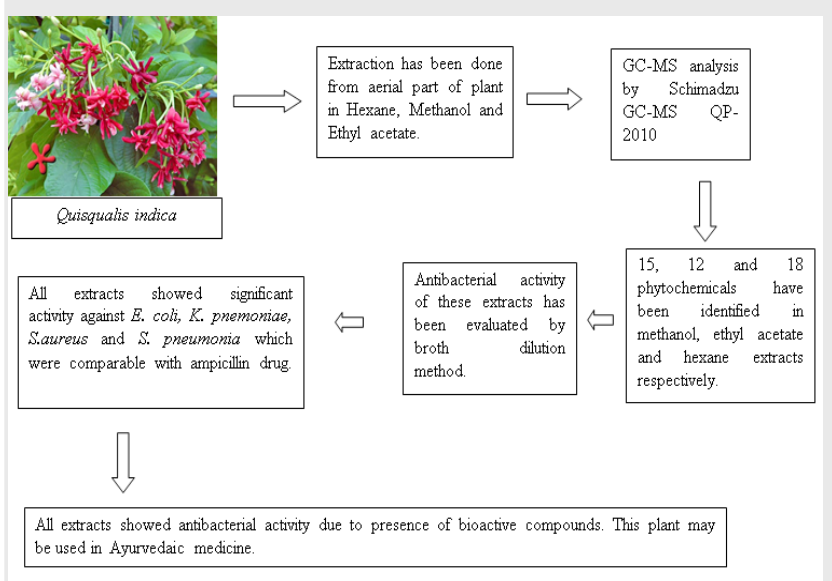

\section{About Authors}
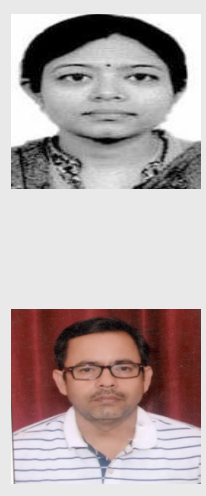

Akriti Agarwal: Has done her PhD in chemistry from University of Lucknow, in 2008. Her doctoral research is focused on Synthesis of biologically active compounds and biosynthesis of phytochemicals of Indian medicinal plants. At present she is working as a Research Associate and she analyses pesticide residues in food commodities by using GC-MS, GC-ECD and GC-FPD. She has worked as a Research Associate in the project "National Monitoring of Persistent Organic Pollutant Pesticides and PCBs in the Environment" under Global Monitoring Plan (GMP) at Indian Agricultural Research Institute (IARI) Pusa, New Delhi.

Dr. Lalitesh Kumar Thakur: has done his doctoral degree in the area of food emulsion \& microemulsion from department of Chemistry, Delhi University. Presently he is working as Specialist \& InchargeAnalytical Division at Institute of Pesticide Formulation Technology, Gurgaon. His area of expertise is pesticide formulations, their quality parameters \& residue analysis in food commodities. For NABL activity, he is working as quality manager. He has successfully completed two research projects \& he has one project on monitoring of pesticide residue at National level sponsored by Ministry of Agriculture, Govt. of India. He has published more than twenty research papers in international journals. He has filed two patents also.

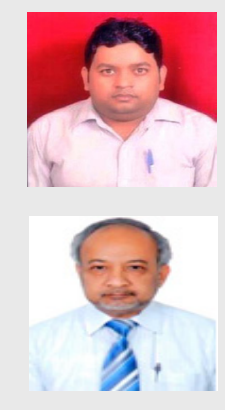

Rajmani Prajapati: $\mathrm{He}$ is a doctoral student at the Gautam Budhha University, Greater Noida (Uttar Pradesh). He has done Master degree in Industrial Chemistry from Jiwaji University, Gwalior. His doctoral research is focused on evaluation of antifungal activity of seed oil and their formulations. He has also an experience on pesticide residue analysis in food commodities by using GC-ECD, FPD and GC-MS detectors.

Dr. Sayed Kalve Raza: Did his doctoral degree in Chemistry from Aligarh Muslim University. He was director of Institute of Pesticide Formulation Technology, Gurgaon from 2011 to 2016. Prior to it, he was senior scientist at DRDE, Gwalior. He has vast experience in mass spectrometry and chemical warfare agents. He has published more than 100 research papers in International journals. He is lead assessor for NABL activity.

Cite this article: Agarwal A, Prajapati R, Raza SK, Thakur LK. GC-MS Analysis and Antibacterial Activity of Aerial Parts of Quisqualis indica Plant Extracts. Indian J of Pharmaceutical Education and Research. 2017;51(2):329-36. 